\title{
An examination of the effect of autumn closing date on over-winter herbage production and spring yield
}

\author{
C. Looney ${ }^{1,2}$, D. Hennessy ${ }^{1}$, A. Wingler ${ }^{2}$, A. Claffey ${ }^{1}$ and M. Egan ${ }^{1 \dagger}$
}

${ }^{1}$ Teagasc, Animal \& Grassland Research and Innovation Centre, Moorepark, Fermoy, Co. Cork, Ireland

${ }^{2}$ School of Biological, Earth and Environmental Sciences and Environmental Research Institute, University College Cork, Distillery Fields, North Mall, Cork, Ireland

Abstract

Altering autumn management affects the herbage mass available in spring. An experiment was established to determine the effect of five autumn closing dates (CDs) on herbage production, herbage quality, leaf, stem and dead proportions and tiller density over winter. In the study $50 \%$ of the herbage available in spring was accounted for by autumn CD. Each $1 \mathrm{~d}$ extra a sward was closed from 25 September to 9 December increased herbage mass by $16 \mathrm{~kg} \mathrm{DM} / \mathrm{ha}$ in spring. Swards closed earlier (25 September-26 October) had consistently higher herbage masses in spring (1,301 kg DM/ha) compared to swards closed later (11 November-9 December; 703 kg DM/ha). Later closed swards had greater herbage quality compared to earlier closed swards (organic matter digestibility $=852$ and $825 \mathrm{~g} / \mathrm{kg}$ DM, respectively) due to increased stem and dead material in the grazing horizon of earlier closed swards. There was no effect of autumn $C D$ on sward quality in the subsequent defoliation in spring. However, following the initial spring grazing there was an effect of autumn $C D$ on subsequent grass growth rates; swards closed in October had a lower growth rate (33 kg DM/ha per day) compared to swards closed in November and early December (49 kg $D M / h a$ per day). Results indicate that earlier autumn closing is beneficial to meet high-feed demand in spring but can affect sward quality and growth rates in spring.

Keywords

Autumn grazing date $\bullet$ herbage mass $\bullet$ spring grass $\bullet$ sward quality

\section{Introduction}

In temperate regions of the world grass-based dairy production systems offer a competitive and sustainable alternative to intensive, high-output systems (Dillon et al., 2008; Peyraud et al., 2010; Ramsbottom et al., 2015). Grazed grass is the cheapest feed source available for ruminant production systems (Finneran et al., 2010), and increasing the production and utilisation of grazed grass is of the utmost importance in improving environmental (Donnellan et al., 2018) and economic (MacDonald et al., 2010; Hanrahan et al., 2018) sustainability. In spring calving systems, which are dominant in Ireland (Dillon et al., 1995; O'Donovan et al., 2011), there are high-feed requirements to meet animal demands in spring. In temperate climatic zones, such as Ireland and New Zealand, there is a high dependence on environmental conditions such as temperature for perennial ryegrass (Lolium perenne L.; $P R G$ ) growth. As a result there is little grass growth during late autumn, winter and early spring (Dillon et al., 1995; Parsons \& Chapman, 2000; Hennessy et al., 2008), which can lead to inadequate quantities of grazed herbage available on farm in spring (Ryan et al., 2010; Lawrence et al., 2017). Autumn closing date $(C D)$ is one of the main factors contributing to the accumulation of herbage over the winter months (Roche et al., 1996; Hennessy et al., 2006). The date on which a sward is grazed in the previous autumn has a direct impact on the amount of grass available in the following spring (Davies \& Simons, 1979; O'Donovan et al., 2002; Lawrence et al., 2017). It has previously been reported that every 1-d delay in closing from 1 October results in a reduction in spring herbage accumulation of between 10 and $15 \mathrm{~kg}$ DM/ha per day in pre-grazing herbage mass (O'Donovan et al., 2002; Lawrence et al., 2017). Closing swards earlier in autumn (early October) can lead to an increase in herbage available 
in spring, which can allow for an earlier turnout of animals (Roche et al., 1996; Hennessy et al., 2006).

Despite low over-winter growth rates on farms in Ireland (3 to $8 \mathrm{~kg} \mathrm{DM} / \mathrm{ha}$ per day; December-January; PastureBase Ireland Data, M. O'Leary, Teagasc, Personal Communication), herbage is continuously accumulating throughout the winter (Brereton et al., 1985) albeit at a slower rate compared to in spring, summer and autumn. When a high herbage mass $(>2,000 \mathrm{~kg}$ $\mathrm{DM} / \mathrm{ha}$; approximately) is carried over winter, it can result in a reduction in sward quality, as the amount of green leaf material in the sward declines and the level of senescent material increases (Hennessy et al., 2008). Additionally, a high herbage mass results in shading which can reduce tiller production and hinder tiller establishment and survival (Laidlaw \& Mayne, 2000). To meet the target of matching animal feed requirements with available herbage in spring, autumn grazing management has been identified as the key controllable management practice on farm (Claffey et al., 2019). Over the last $10 \mathrm{yr}$ (2008-2017), the 6-wk calving rate on Irish dairy farms has increased from $61 \%$ to $72 \%$, while the mean calving date has reduced by $8 \mathrm{~d}$ (Dillon et al., 2018). The proportion of cows calving between January and April has increased from $74 \%$ in 2008 to $84 \%$ in 2018 (ICBF, 2018). This coupled with an increase in average herd size from 48 cows in 2005 to 76 cows in 2016 (Kelly et al., 2020), and an increase in the whole farm stocking rate from 1.7 to $1.9 \mathrm{LU} / \mathrm{ha}$ (Hanrahan et al., 2018) has resulted in an increase in dairy cow feed demand on Irish farms in spring. This increased demand must be met through increased grass growth and utilisation if farms are to remain economically sustainable (Dillon et al., 2005). Current autumn grazing recommendations in Ireland are that the farm begins closing in early October; $60 \%$ of the farm is closed from grazing by 1 November, with a closing average farm cover (AFC; amount of grass available on farm) of between 650 and $750 \mathrm{~kg} \mathrm{DM} / \mathrm{ha}$ (3.5 $\mathrm{cm}$ above ground level) on 1 December and an opening average farm cover in spring of approximately $1,000 \mathrm{~kg} \mathrm{DM} / \mathrm{ha}$ (Teagasc, 2019; Claffey et al., 2020). One option to increase spring grass availability is to close swards early in autumn and thereby carry a greater quantity of grass over winter into spring (Hennessy et al., 2006).

Previous research in the area of autumn CD has been carried out in plot studies (Carton et al., 1988; Hennessy et al., 2006; Lawrence et al., 2017), within grazing studies (Roche et al., 1996; Ryan et al., 2010) or on commercial farms (O'Donovan et al., 2002). However, much of this work was prior to the rapid expansion within the Irish dairy industry (Kelly et al., 2020). Grazing management practices have not evolved to meet increased herd demand in spring in line with increased stocking densities and earlier and more compact calving. Earlier autumn closing has been recommended as a strategy to help meet the herbage demand in spring (Claffey et al., 2019). Some of the previous studies that investigated autumn CDs over multiple years (Hennessy et al., 2006; Lawrence et al., 2017) had very early autumn closing (10 August-10 October), and the grazing dates did not represent that of a dairy farm in spring (20 November-20 February; Hennessy et al., 2006). Closing swards over a period in autumn followed by spring defoliation is more representative of grazing management practices on farm. Additionally, little research has taken place on the impact of autumn CD on the regrowth of swards in spring following initial defoliation. There is still potential to improve both autumn and spring grazing management recommendations through a multiple-year study that is representative of on-farm autumn CDs and spring grazing requirements.

The objective of this experiment was to investigate the effect of closing paddocks between late September and early December on over-winter herbage production, herbage quality, leaf, stem and dead proportions, tiller density in spring and the subsequent effects on herbage production.

\section{Materials and methods}

The experiment was conducted at the Teagasc, Animal and Grassland Research and Innovation Centre, Moorepark, Fermoy, Co. Cork, Ireland (Latitude $50^{\circ} 07^{\prime} \mathrm{N}$, Longitude $08^{\circ} 16^{\prime} \mathrm{W}$ ) from August 2016 to April 2019. The paddocks were approximately $40 \mathrm{~m}$ above sea level with a south-facing aspect. The soil type was a free-draining acid brown earth of sandy to loam texture (Teagasc, 2017). Swards were predominantly PRG $(>85 \%)$ plus $<15 \%$ broadleaf plants and weed grass including, white clover (Trifolium repens L.) and annual meadow grass (Poa annua L.). Soils had a pH of 6.8 $( \pm 0.2)$, phosphorus $(P)$ index of $3.8( \pm 0.4)$ and potassium $(K)$ index of $3.3( \pm 0.8$; scale 1 to $4 ; 1=$ deficient, $4=$ no response to application of nutrient; Alexander et al., 2008). This study was undertaken within a larger grazing experiment (Claffey et al., 2019, 2020), where the rotation length of the grazing treatments dictated the CDs and initial spring grazing date. Briefly, the larger farm systems study had three autumn closing management treatments: Early (25 September9 November), Normal (10 October-24 November) and Late (25 October-9 December). A total of 30.6 ha were randomised into three farmlets, with each farmlet split into paddocks and grazed by equal groups of 30 lactating dairy cows, and based on autumn closing treatment. The target post-grazing sward height in autumn and spring were $3.5 \mathrm{~cm}$. The actual postgrazing sward height achieved was $4 \pm 0.05 \mathrm{~cm}$ in autumn and $3.6 \pm 0.06 \mathrm{~cm}$ in spring. All animals were turned out in spring on 5 February $( \pm 2 \mathrm{~d})$ regardless of autumn closing treatment. Across all farmlets in spring the daily area allocated to the each grazing group was similar across the first rotation, concentrate supplementation in spring was similar for each grazing group 
(3 $\mathrm{kg} \mathrm{DM} /$ cow per d) and silage was only supplemented to individual groups if the post-grazing sward height went below $3.5 \mathrm{~cm}$ (Claffey et al., 2019). For the remainder of the year (second rotation to July, rotation length was gradually extended in late July to allow autumn closing managements to be implemented) all swards were grazed in a 21-d rotational grazing system to a target post-grazing sward height of $4 \mathrm{~cm}$ in line with Teagasc recommendations (Teagasc, 2011).

From the farmlet study, 36 paddocks were chosen in year 1 (2016-2017), 48 in year 2 (2017-2018) and 48 in year 3 (20182019). The last defoliation of paddocks (swards hereafter) for the season was between 25 September and 9 December. Swards were assigned to each of the five CD treatments; the number of swards assigned to each treatment is shown in Table 1. Sward numbers differed for each CD in each year as the overall farm systems experiment dictated grazing dates; the grazing dates of the individual paddocks then fell independently into the allocated CD treatments (Table 1). The mean $C D$ of each of the treatments was 4 October (CD1), 19 October (CD2), 3 November (CD3), 18 November (CD4) and 3 December (CD5). Following the final grazing, swards remained un-defoliated until the following spring. Herbage mass $>3.5 \mathrm{~cm}$ was measured on three measurement dates (MD) over winter (Table 1) - MD1 (12 December; average), MD2 (9 January) and MD3 (2 February). Initial spring grazing took place independently of $\mathrm{CD}$ over an 8-wk period from 11 February to 8 April. Spring grazing (MD4) followed the current Teagasc recommendations (Teagasc, 2020) to reflect what happens on farm. Grazing in MD5 followed sequentially from grazing in MD4. Immediately prior to the first grazing in spring herbage mass was measured (MD4) on each individual sward. Final herbage measurement on each sward was taken immediately prior to second defoliation in spring (second rotation; MD5). Nitrogen fertiliser was applied in the form of urea at a rate of $53.6 \mathrm{~kg} \mathrm{~N} / \mathrm{ha}$ between January and midMarch and at a rate of $26.4 \mathrm{~kg} \mathrm{~N} / \mathrm{ha}$ in mid-April. In mid-April, phosphorus (9.6 kg P/ha) and potassium (19.2 kg K/ha) were applied.

\section{Measurements}

\section{Meteorological data}

Meteorological data were recorded at the experimental site for the duration of the experiment. Average daily air temperature $\left({ }^{\circ} \mathrm{C}\right)$, soil temperature to a depth of $100 \mathrm{~mm}\left({ }^{\circ} \mathrm{C}\right)$, total daily rainfall $(\mathrm{mm})$ and average solar radiation are shown for the measurement periods in each experimental year (Table 2).

\section{Herbage mass}

Herbage mass (>3.5 cm; targeted residual) was determined by cutting two strips $1.2 \mathrm{~m}$ wide by a known length (approximately $10 \mathrm{~m}$ ) in the swards using an Etesia mower
Table 1: Closing date treatments (CD; CD1 [27 Sept-11 Oct], CD2 [12 Oct-26 Oct], CD3 [27 Oct-10 Nov], CD4 [11 Nov-25 Nov] and CD5 [26 Nov-9 Dec]) applied in autumn, the number of paddocks allocated per treatment, and measurement dates (MD; MD1 [12 Dec], MD2 [9 Jan], MD3 [2 Feb], MD4 [first defoliation] and MD5 [second defoliation]) over the experimental period

\begin{tabular}{|c|c|c|c|}
\hline Treatment $^{1}$ & Mean $\mathrm{CD}^{2}$ & 2-wk interval & No. of days closed ${ }^{3}$ \\
\hline CD1 & 4 Oct & 25 Sept-11 Oct & 121 \\
\hline $\mathrm{CD} 2$ & 19 Oct & 12 Oct-26 Oct & 106 \\
\hline CD3 & $3 \mathrm{Nov}$ & 27 Oct-10 Nov & 91 \\
\hline CD4 & $18 \mathrm{Nov}$ & 11 Nov-25 Nov & 76 \\
\hline CD5 & $3 \mathrm{Dec}$ & 26 Nov-9 Dec & 61 \\
\hline \multicolumn{4}{|c|}{ No. of paddocks per CD } \\
\hline & Year 1 & Year 2 & Year 3 \\
\hline CD1 & 8 & 9 & 10 \\
\hline $\mathrm{CD} 2$ & 5 & 13 & 12 \\
\hline CD3 & 16 & 15 & 12 \\
\hline $\mathrm{CD} 4$ & 7 & 5 & 12 \\
\hline \multirow[t]{2}{*}{ CD5 } & 0 & 6 & 2 \\
\hline & \multicolumn{3}{|c|}{ Measurement date } \\
\hline $\mathrm{MD}^{4}$ & \multicolumn{3}{|c|}{$12 \mathrm{Dec}$} \\
\hline MD2 & \multicolumn{3}{|c|}{9 Jan } \\
\hline MD3 & \multicolumn{3}{|c|}{$2 \mathrm{Feb}$} \\
\hline MD4 & \multicolumn{3}{|c|}{ First defoliation (6 Feb-5 April) } \\
\hline \multirow[t]{2}{*}{ MD5 } & \multicolumn{3}{|c|}{ Second defoliation (6-30 April) } \\
\hline & \multicolumn{3}{|c|}{ Measurement period } \\
\hline MP1 & \multicolumn{3}{|c|}{ Paddock closing-12 Dec } \\
\hline MP2 & \multicolumn{3}{|c|}{13 Dec-9 Jan } \\
\hline MP3 & \multicolumn{3}{|c|}{10 Jan-2 Feb } \\
\hline MP4 & \multicolumn{3}{|c|}{3 Feb-first defoliation } \\
\hline MP5 & \multicolumn{3}{|c|}{ First defoliation-second defoliation } \\
\hline
\end{tabular}

${ }^{1}$ Treatment is the autumn closing date applied to swards: CD1 = closing date $1, \mathrm{CD} 2=$ closing date $2, \mathrm{CD} 3=$ closing date $3, \mathrm{CD} 4=$ closing date 4 and $\mathrm{CD} 5=$ closing date 5 .

${ }^{2}$ Mean date for each 2-wk interval per treatment.

${ }^{3}$ Number of days closed for each closing date between the mean CD and measurement date 3 (2 February).

${ }^{4}$ Measurement dates on swards: MD1 = measurement date $1=12$ Dec, MD2 = measurement date $2=9 \mathrm{Jan}, \mathrm{MD} 3=$ measurement date $3=2 \mathrm{Feb}, \mathrm{MD} 4=$ measurement date $4=$ first defoliation in spring, MD5 $=$ measurement date $5=$ second defoliation in spring.

(Etesia UK Ltd., Warwick, UK). The mown herbage from each strip was collected and weighed. A sample of approximately $300 \mathrm{~g}$ was collected from each cut strip. A sub-sample of $100 \mathrm{~g}$ was weighed and dried for $16 \mathrm{~h}$ at $90^{\circ} \mathrm{C}$ to determine dry matter (DM) content. Compressed sward height was recorded pre- and post-cutting on each cut strip by taking 
Table 2: Average daily air temperature, mean soil temperature, total rainfall and average solar radiation between September and April for year 1 (2016/2017), year 2 (2017/2018) and year 3 (2018/2019) and the 10-yr average (2006-2016) at the experimental site

\begin{tabular}{|c|c|c|c|c|c|c|c|c|c|}
\hline & Sept. & Oct. & Nov. & Dec. & Jan. & Feb. & Mar. & Apr. & Mean \\
\hline \multicolumn{10}{|c|}{ Average daily air temp $\left({ }^{\circ} \mathrm{C}\right)$} \\
\hline Year $1-2016 / 2017$ & 13.9 & 10.6 & 5.2 & 6.7 & 6.3 & 6.6 & 8.3 & 8.7 & 8.3 \\
\hline Year $2-2017 / 2018$ & 12.9 & 11.5 & 7.2 & 6.3 & 6.3 & 4.0 & 4.7 & 9.0 & 7.7 \\
\hline Year $3-2018 / 2019$ & 12.4 & 9.9 & 8.1 & 8.5 & 6.5 & 7.7 & 7.5 & 9.1 & 8.7 \\
\hline 10-yr average & 13.3 & 10.9 & 7.6 & 5.7 & 5.4 & 5.5 & 6.4 & 8.7 & 7.9 \\
\hline \multicolumn{10}{|c|}{ Mean soil temp to a depth of $100 \mathrm{~mm}\left({ }^{\circ} \mathrm{C}\right)$} \\
\hline Year $1-2016 / 2017$ & 15.0 & 11.0 & 5.7 & 6.2 & 5.8 & 6.6 & 8.4 & 10.9 & 8.7 \\
\hline Year $2-2017 / 2018$ & 14.7 & 12.3 & 8.1 & 5.6 & 5.5 & 4.0 & 5.4 & 10.0 & 8.2 \\
\hline Year $3-2018 / 2019$ & 14.6 & 10.8 & 7.8 & 8.0 & 6.8 & 7.3 & 8.3 & 10.6 & 9.3 \\
\hline 10 -yr average & 15.0 & 11.9 & 7.9 & 5.4 & 5.0 & 5.4 & 6.9 & 10.2 & 8.5 \\
\hline \multicolumn{10}{|l|}{ Total rainfall $(\mathrm{mm})$} \\
\hline Year 1 - 2016/2017 & 98.6 & 27.9 & 44.5 & 84.7 & 85.3 & 108.4 & 115.8 & 35.6 & 75.1 \\
\hline Year $2-2017 / 2018$ & 115.7 & 102.2 & 65.5 & 110.4 & 138.4 & 40.4 & 88.5 & 174.8 & 104.5 \\
\hline Year $3-2018 / 2019$ & 60.0 & 72.4 & 167.1 & 168.2 & 65.9 & 56.7 & 117.9 & 108.9 & 102.1 \\
\hline 10-yr average & 67.5 & 105.5 & 116.8 & 113.2 & 122.5 & 82.6 & 68.7 & 58.8 & 92.0 \\
\hline \multicolumn{10}{|c|}{ Average solar radiation $\left(\mathrm{MJ} / \mathrm{m}^{2}\right)$} \\
\hline Year $1-2016 / 2017$ & 895 & 623 & 375 & 169 & 262 & 445 & 821 & 1,108 & 587 \\
\hline Year $2-2017 / 2018$ & 1,026 & 477 & 335 & 189 & 264 & 552 & 770 & 1,080 & 587 \\
\hline Year $3-2018 / 2019$ & 1,074 & 691 & 267 & 176 & 247 & 484 & 937 & 1,316 & 649 \\
\hline 8 -yr average ${ }^{1}$ & 964 & 560 & 320 & 192 & 249 & 408 & 825 & 1,314 & 604 \\
\hline
\end{tabular}

${ }^{1}$ Data presented from 2008 to 2016.

10 measurements per strip using a rising plate meter (Jenquip Rising Plate Pasture Meter, Feilding, New Zealand). This was used to calculate the sward density (cut herbage mass [kg $\mathrm{DM} /$ ha]/[pre-cutting height - post-cutting height]). Herbage mass was then corrected for post-grazing sward height using the following equation (Delaby et al., 1998):

Corrected Herbage mass $(>3.5 \mathrm{~cm})$

$$
\begin{aligned}
& =(\text { pre cutting compressed sward height } \\
& - \text { targeted residual }(3.5 \mathrm{~cm})) \times \text { sward density }
\end{aligned}
$$

Grass growth rate was calculated by dividing the corrected herbage mass by the number of days closed.

\section{Herbage quality analysis}

Selected herbage samples were taken at random from each sward, prior to spring grazing and in the second rotation. The method used was designed to select herbage representative of what cows would consume from the sward based on observation of the previous days grazing. The method used was that described by Ganche et al. (2013); samples were taken using handheld Gardena shears (Accu 90, Gardena International $\mathrm{GmbH}$, Ulm, Germany) cut to grazing height and stored at $-18^{\circ} \mathrm{C}$. The frozen herbage was bowl-chopped (Muller, Type MKT 204 Special, Saabrücken, Germany), freeze-dried at $-50^{\circ} \mathrm{C}$ for $120 \mathrm{~h}$ and milled through a 1-mm screen using a Cyclotech 1093 Sample Mill (Foss, DK-3400 Hillerød, Denmark). The chemical composition was analysed by wet chemistry for organic matter digestibility (OMD; $\mathrm{g} / \mathrm{kg}$ ), crude protein (CP; g/kg DM), neutral detergent fibre (NDF), acid detergent fibre (ADF) and ash (AOAC, 1995; method 942.05) concentrations. The OMD was estimated using the in vitro neutral detergent cellulase method as described by Morgan et al. (1989) (FibertecTM Systems; Foss, Ballymount, Dublin). Crude protein concentration was determined using an $\mathrm{N}$ analyser (Leco FP-428; Leco Australia Pty Ltd, Baulkham Hills B.C. NSW, Australia) based on the AOAC method 99003 (AOAC, 1990). The NDF and ADF concentrations were determined using a fibre analyser (AOAC, 1995, method 973.18; Ankom Technology, Macedon, NY, USA) based on the method described by Van Soest et al. (1991). Amylase and a sodium sulphate solution were used in the NDF concentration 
determination process. Ash concentration was estimated by burning a sub-sample in a muffle furnace at $500^{\circ} \mathrm{C}$ for $12 \mathrm{~h}$.

\section{Tiller density}

Five turves $(0.1 \mathrm{~m} \times 0.1 \mathrm{~m})$ were cut to a depth of $0.05 \mathrm{~m}$ and removed from each sward twice during per year (December and February). Turves were removed along a "W" shape across the paddock at approximately $25 \mathrm{~m}$ intervals to take into account the heterogeneity of the swards (Jewiss, 1993). The grass tillers in each turve were separated into PRG and other grass species (mainly meadow grass, $P$. annua L.) and counted. From these turves, an overall average tiller density per $\mathrm{m}^{2}$ was calculated.

\section{Perennial ryegrass leaf, stem and dead proportion}

Perennial ryegrass leaf, stem and dead proportions $>3.5 \mathrm{~cm}$ were measured in each sward prior to grazing in spring (MD4) as described by McCarthy et al. (2013). Briefly, at eight randomly chosen locations within each sward, PRG tillers were cut to ground level and the vertical structure was maintained, a sub-sample of $40 \mathrm{~g}$ was selected and the lower horizon $(<3.5 \mathrm{~cm})$ was then removed. The remaining herbage $(>3.5 \mathrm{~cm})$ was divided into leaf, stem and dead components. The fresh weight of each component was recorded before drying at $90^{\circ} \mathrm{C}$ for $16 \mathrm{~h}$ to determine the DM proportions $(>3.5 \mathrm{~cm})$ of the leaf, stem and dead material. From the DM proportions the masses of green leaf, stem and dead in the overall herbage mass harvested were calculated.

\section{Statistical analysis}

Statistical analysis was carried out using SAS 9.4 (SAS Institute Inc., Cary, NC, USA). The effect of CD on herbage mass, growth rate, tiller density, green leaf mass, stem mass, dead leaf mass, OMD, CP, NDF, ADF and ash were determined using the PROC MIXED procedure with $C D, M D$ and year included in the model. Measurement date was the repeated measure and sward was the experimental unit. Data are presented as least square means \pm standard error. Variables were analysed using the following model:

$$
\begin{aligned}
Y_{j k l}= & \mu+\text { closing date }_{j}+\text { measurement date }_{k} \\
& + \text { year }_{l}\left(\text { closing date }_{j} \times \text { measurement date }_{k}\right. \\
& \left.\times \text { year }_{l}\right)+\left(\text { closing date }_{j} \times \text { measurement date }_{k}\right) \\
& +\left(\text { year }_{1} \times \text { closing date }_{j}\right)+\left(\text { closing date }_{j}\right. \\
& \left.\times \text { measurement date }_{k}\right) \times e_{j k l}
\end{aligned}
$$

where:

$\mu=$ mean value for the variable

$e_{j k l}=$ residual error term
$Y_{j k l}=$ herbage mass (kg DM/ha), growth rate ( $\mathrm{kg} \mathrm{DM} / \mathrm{ha}$ per day), tiller density $\left(\mathrm{m}^{2}\right)$, green leaf mass ( $\mathrm{kg} \mathrm{DM} / \mathrm{ha}$ ), stem leaf mass (kg DM/ha), dead leaf mass (kg DM/ha), OMD ( $/ \mathrm{kg}$

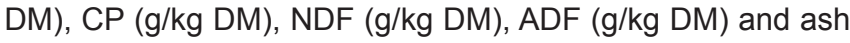
$(\mathrm{g} / \mathrm{kg} \mathrm{DM})$ with sward as the experimental unit.

\section{Results}

Weather data collected during the experimental period (September to April) are summarised in Table 2. In year 3 the daily air and soil temperature at $100 \mathrm{~mm}$ were greatest $\left(8.7\right.$ and $9.3^{\circ} \mathrm{C}$, respectively) compared to year 1 (8.3 and $8.7^{\circ} \mathrm{C}$, respectively) and year $2\left(7.7\right.$ and $8.2^{\circ} \mathrm{C}$, respectively). Monthly rainfall was similar in years 2 and 3 (104.5 and $102.1 \mathrm{~mm}$, respectively) and was lower in year $1(75.1 \mathrm{~mm})$. Monthly solar radiation was the same in years 1 and $2\left(587 \mathrm{MJ} \mathrm{m}^{2}\right)$ and was greater in year $3\left(649 \mathrm{MJ} \mathrm{m}^{2}\right)$.

\section{Grass growth rate}

Growth rates over winter were significantly $(P<0.001)$ affected by the interaction between CD and MD (Table 3). On MD2, CD3 and CD4 had a lower growth rate than CD5 and CD1, with CD2 intermediate (Table 3). On MD5, CD5 had a greater growth rate compared to CD2 with $\mathrm{CD} 1$, and $\mathrm{CD} 3$ and $\mathrm{CD} 4$ were intermediate to both (Table 3 ). Growth rates were significantly $(P<0.001)$ affected by the interaction between MD and year (Table 4). In year 3, MD2 (9.6 $\pm 0.56 \mathrm{~kg} \mathrm{DM} / \mathrm{ha}$ per day) had a greater growth rate than in year 1 and year $2(5.6 \pm 0.64 \mathrm{~kg}$ $\mathrm{DM} / \mathrm{ha}$ per day, average). In year 3, MD4 (4.4 $\pm 1.11 \mathrm{~kg} \mathrm{DM} / \mathrm{ha}$ per day) had a lower growth rate than in year 1 and year $2(12.2$ $\pm 1.35 \mathrm{~kg} \mathrm{DM} / \mathrm{ha}$ per day). Closing date and MD significantly $(P<0.001)$ affected the average growth rate (Table 3$)$. Average growth rate varied significantly $(P<0.001)$ by year, with the greatest growth rate in year $1(28.0 \pm 1.65 \mathrm{~kg} \mathrm{DM} / \mathrm{ha}$ per day), the lowest in year $2(24.9 \pm 1.49 \mathrm{~kg} \mathrm{DM} / \mathrm{ha}$ per day $)$ and year 3 (26.9 $\pm 1.89 \mathrm{~kg} \mathrm{DM} / \mathrm{ha}$ per day) was intermediate.

\section{Herbage mass}

There was a significant effect $(P<0.001)$ of the MD $\times$ year interaction on herbage mass (Table 4). Herbage mass on MD2 was lower in year $2(432 \pm 55.8 \mathrm{~kg} \mathrm{DM} / \mathrm{ha}$ ) compared to year $3(710 \pm 56.2 \mathrm{~kg} \mathrm{DM} / \mathrm{ha})$. In year $2 \mathrm{MD} 3$ had a lower herbage mass $(611 \pm 59.8 \mathrm{~kg} \mathrm{DM} / \mathrm{ha}$ ) compared to year 3 (836 $\pm 58.6 \mathrm{~kg} \mathrm{DM} / \mathrm{ha})$. There was a significant effect $(P<0.001)$ of $C D$ on spring grass availability; each 1-d delay in closing from 25 September resulted in a reduction of $16 \mathrm{~kg} \mathrm{DM} / \mathrm{ha}$ in herbage mass (Figure 1) on 6 February. Measurement date had a significant effect $(P<0.001)$ on herbage mass. Average herbage mass across all treatments was the greatest on MD5 (1,652 $\pm 77.5 \mathrm{~kg} \mathrm{DM} / \mathrm{ha})$, followed by MD4 $(981 \pm 45.9 \mathrm{~kg} \mathrm{DM} / \mathrm{ha})$ and MD3 $(713 \pm 37.1 \mathrm{~kg} \mathrm{DM} / \mathrm{ha})$ with 
Table 3: The effect of five autumn closing dates (CD), CD1 (27 Sept-11 Oct), CD2 (12 Oct-26 Oct), CD3 (27 Oct-10 Nov), CD4 (11 Nov-25

Nov) and CD5 (26 Nov-9 Dec), on the over winter growth rate ( $\mathrm{kg} \mathrm{DM} / \mathrm{d})$ and herbage mass ( $\mathrm{kg} \mathrm{DM} / \mathrm{ha}$ ) in winter over five consecutive measurement dates, MD1 (12 Dec), MD2 (9 Jan), MD3 (2 Feb), MD4 (first defoliation in spring) and MD5 (second defoliation in spring) over 3 yr (year 1 [2016/2017], year 2 [2017/2018] and year 3 [2018/2019])

\begin{tabular}{|c|c|c|c|c|c|c|c|c|c|}
\hline & \multirow[t]{2}{*}{$\mathrm{CD}^{1}{ }^{1}$} & \multirow[t]{2}{*}{ CD2 } & \multirow[t]{2}{*}{ CD3 } & \multirow[t]{2}{*}{ CD4 } & \multirow[t]{2}{*}{ CD5 } & \multirow[t]{2}{*}{ S.E. } & \multicolumn{3}{|c|}{$P$-value } \\
\hline & & & & & & & CD & MD & $C D \times M D$ \\
\hline \multicolumn{10}{|c|}{ Growth rate (kg DM/ha per day) } \\
\hline $\mathrm{MD}^{2}{ }^{2}$ & 14.9 & 12.0 & 10.2 & 13.9 & $--^{3}$ & 2.38 & $* * *$ & $* * *$ & $* * *$ \\
\hline MD2 & 10.5 & 8.0 & 5.5 & 6.2 & 12.3 & & & & \\
\hline MD3 & 12.3 & 9.4 & 9.7 & 8.6 & 8.5 & & & & \\
\hline MD4 & 12.8 & 12.9 & 12.2 & 8.3 & 9.3 & & & & \\
\hline MD5 & 39.9 & 32.6 & 38.8 & 35.8 & 49.4 & & & & \\
\hline \multicolumn{10}{|c|}{ Herbage mass (kg DM/ha) } \\
\hline MD1 & 1,056 & 604 & 372 & 292 & 262 & 93.1 & $* * *$ & $* * *$ & \\
\hline MD2 & 1,003 & 646 & 368 & 321 & 433 & & & & \\
\hline MD3 & 1,210 & 794 & 504 & 468 & 413 & & & & \\
\hline MD4 & 1,544 & 1,058 & 809 & 626 & 779 & & & & \\
\hline MD5 & 1,823 & 1,545 & 1,693 & 1,429 & 1,501 & & & & \\
\hline
\end{tabular}

${ }^{1}$ Autumn closing date applied to swards: CD1 $=27$ Sept-11 Oct, CD2 = 12 Oct-26 Oct, CD3 = 27 Oct-10 Nov, CD4 = 11 Nov-25 Nov and CD5 = 26 Nov-9 Dec.

${ }^{2}$ Measurement dates on swards: $\mathrm{MD} 1=$ measurement date $1=12 \mathrm{Dec}, \mathrm{MD} 2=$ measurement date $2=9$ Jan, MD3 = measurement date $3=2$ Feb, MD4 = measurement date $4=$ first defoliation in spring, MD5 = measurement date $5=$ second defoliation in spring.

${ }^{3} \mathrm{CD} 5$ on MD1 is excluded due to a short closed period (9 d).

Table 4: The effect of the interaction of year (year 1 [2016/2017], year 2 [2017/2018] and year 3 [2018/2019]) and measurement date (MD1 [12 Dec], MD2 [9 Jan], MD3 [2 Feb], MD4 [first defoliation in spring] and MD5 [second defoliation in spring]) on growth rate (kg $\mathrm{DM} / \mathrm{ha}$ per day) and herbage mass ( $\mathrm{kg} \mathrm{DM} / \mathrm{ha}$ )

\begin{tabular}{lccccccc}
\hline & Year 1 & Year 2 & Year 3 & \multicolumn{3}{c}{$P$-value } \\
\hline \multicolumn{2}{l}{ Growth rate (kg DM/ha per day) } & S.E. & MD & Year & MD * yr \\
\hline MD1 & -2 & 14.3 & 15.4 & 3.40 & $* *$ & $* *$ & $* * *$ \\
MD2 & 5.6 & 6.4 & 9.6 & & & & \\
MD3 & 16.2 & 8.2 & 7.2 & & & & \\
MD4 & 13.4 & 13.1 & 7.4 & & & & \\
MD5 & 46.5 & 37.9 & 31 & & & & \\
Herbage mass (kg DM/ha) & & & & & \\
MD1 & - & 485 & 572 & 123.0 & $* *$ & $* *$ & $* * *$ \\
MD2 & 426 & 480 & 710 & & & & \\
MD3 & 716 & 574 & 836 & & & & \\
MD4 & 1,329 & 864 & 836 & & & & \\
MD5 & 1,412 & 1,729 & 1,768 & & & & \\
\hline \multicolumn{7}{l}{} \\
\hline
\end{tabular}

${ }^{1}$ Measurement dates on swards: MD1 = measurement date $1=12$ Dec, MD2= measurement date 2 = 9 Jan, MD3 = measurement date $3=2 \mathrm{Feb}, \mathrm{MD} 4=$ measurement date $4=$ first defoliation in spring, MD5 $=$ measurement date $5=$ second defoliation in spring.

${ }^{2}$ In year 1, MD1 excluded due to a low number of recordings.

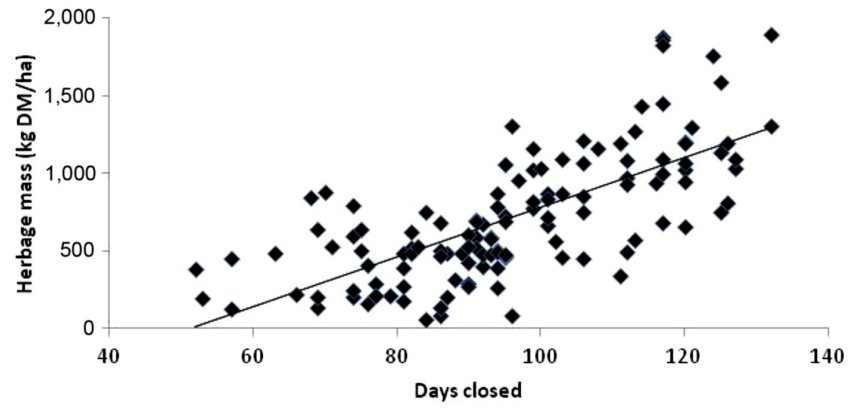

Figure 1. The relationship between the number of days a paddock was un-defoliated over winter, averaged over 3 yr (2016-2019) and the herbage available in MD3 (2 February). The relationship is described by the equation $y=16.11 \times-826.33$. $R 2=0.50$.

the lowest herbage mass on MD1 and MD2 (average $547 \pm$ $36.8 \mathrm{~kg} \mathrm{DM} / \mathrm{ha})$. Herbage mass was significantly $(P<0.001)$ affected by year being lower in year $2(837 \pm 51.0 \mathrm{~kg} \mathrm{DM} / \mathrm{ha})$ than years 1 and 3 (average, $956 \pm 46.6 \mathrm{~kg} \mathrm{DM} / \mathrm{ha}$ ).

\section{Herbage quality}

The effect of $C D$, year and the $C D \times$ year interaction on the OMD, CP, Ash, ADF and NDF on MD4 and MD5 are reported in Table 5. 
Table 5: The effect of five autumn closing dates (CD; CD1 [27 Sept-11 Oct], CD2 [12 Oct-26 Oct], CD3 [27 Oct-10 Nov], CD4 [11 Nov-25 Nov] and CD5 [26 Nov-9 Dec]) on sward quality including organic matter digestibility (OMD g/kg DM), crude protein (CP g/kg DM), ash, acid detergent fibre (ADF g/kg DM) and neutral detergent fibre (NDF; g/kg DM) on measurement date (MD) 4 (first defoliation in spring) and MD5 (second defoliation in spring) over 3 yr (year 1 [2016/2017], year 2 [2017/2018] and year 3 [2018/2019])

\begin{tabular}{|c|c|c|c|c|c|c|c|c|c|c|}
\hline \multirow[b]{2}{*}{$\mathrm{MD}^{1}$} & \multicolumn{7}{|c|}{ Closing date } & \multicolumn{3}{|c|}{$P$-value } \\
\hline & $\operatorname{Var}^{2}$ & $\mathrm{CD} 1^{3}$ & CD2 & CD3 & CD4 & CD5 & S.E. & CD & Year & $C D \times y r$ \\
\hline \multirow[t]{5}{*}{4} & $\mathrm{OMD}^{4}$ & 825 & 826 & 844 & 843 & 852 & 6.3 & $* * *$ & & * \\
\hline & $\mathrm{CP}^{5}$ & 244 & 222 & 250 & 277 & 253 & 1.6 & $* * *$ & * & $* * *$ \\
\hline & Ash $^{6}$ & 86 & 83 & 84 & 84 & 83 & 4.2 & & $* * *$ & \\
\hline & $\mathrm{ADF}^{7}$ & 277 & 211 & 217 & 219 & 245 & 6.1 & * & $* * *$ & \\
\hline & $\mathrm{NDF}^{8}$ & 398 & 398 & 375 & 381 & 399 & 6.1 & * & ** & \\
\hline \multirow[t]{5}{*}{5} & OMD & 856 & 860 & 858 & 860 & 864 & 3.9 & & & \\
\hline & $\mathrm{CP}$ & 245 & 231 & 242 & 230 & 250 & 6.7 & & & \\
\hline & Ash & 89 & 87 & 87 & 86 & 90 & 2. 1 & & $* * *$ & \\
\hline & ADF & 228 & 226 & 229 & 218 & 255 & 6.6 & & *** & \\
\hline & NDF & 407 & 404 & 397 & 398 & 412 & 9.6 & & $\star * *$ & \\
\hline
\end{tabular}

${ }^{1}$ Measurement dates on swards: MD1 = measurement date $1=12$ Dec, MD2= measurement date $2=9$ Jan, MD3 = measurement date $3=2$ Feb, MD4 = measurement date $4=$ first defoliation in spring, MD5 = measurement date $5=$ second defoliation in spring.

${ }^{2}$ Variables measured for quality analysis.

${ }^{3}$ Autumn closing date applied to swards: CD1 $=27$ Sept-11 Oct, CD2 $=12$ Oct-26 Oct, CD3 = 27 Oct-10 Nov, CD4 = 11 Nov-25 Nov and CD5 $=26$ Nov-9 Dec.

${ }^{4} \mathrm{OMD}=$ organic matter digestibility $(\mathrm{g} / \mathrm{kg} \mathrm{DM})$.

${ }^{5} \mathrm{CP}=$ crude protein $(\mathrm{g} / \mathrm{kg} \mathrm{DM})$.

${ }^{6} \mathrm{Ash}(\mathrm{g} / \mathrm{kg} \mathrm{DM})$.

${ }^{7} \mathrm{ADF}=$ acid detergent fibre $(\mathrm{g} / \mathrm{kg} \mathrm{DM})$.

${ }^{8} \mathrm{NDF}=$ neutral detergent fibre (g/kg DM).

\section{Measurement Period 4}

Organic matter digestibility was significantly $(P<0.001)$ affected by CD; CD1 and CD2 had a lower OMD than CD5. The $\mathrm{CD} \times$ year interaction significantly affected $(P<0.05) \mathrm{OMD}$; in year $2 \mathrm{CD} 1$ and CD2 (average, $821 \pm 7.5 \mathrm{~g} / \mathrm{kg} \mathrm{DM}$ ) were lower compared to CD5 (874 $\pm 13.1 \mathrm{~g} / \mathrm{kg} \mathrm{DM})$, and all other CDs were intermediate $(840 \pm 8.1 \mathrm{~g} / \mathrm{kg} \mathrm{DM})$. Organic matter digestibility was significantly $(P<0.05)$ affected by $C D$ and was lower on CD2 compared to CD5 (Table 5). Year had no effect on OMD. There was a significant effect $(P<0.001)$ of $C D \times$ year on $\mathrm{CP}$ concentration; in year 3 CD3 $(188 \pm 9.3 \mathrm{~g} / \mathrm{kg} \mathrm{DM})$ had lower CP concentration compared to CD4 and CD5 (258 $\pm 11.9 \mathrm{~g} / \mathrm{kg}$ DM). Closing date had a significant effect $(P<0.001)$ on CP; CD2 had a lower CP compared to CD1, CD3 and CD4 (Table 5). CP was significantly affected $(P<0.05)$ by year. Year $1(258$ $\pm 5.4 \mathrm{~g} / \mathrm{kg} \mathrm{DM})$ had a greater CP than year 2 and year $3(240$ $\pm 5.4 \mathrm{~g} / \mathrm{kg} \mathrm{DM}$ ).

There was no significant effect of $C D$ or MD on ash content. Ash content was significantly $(P<0.001)$ greater in year 3 (88 $\pm 1.3 \mathrm{~g} / \mathrm{kg} \mathrm{DM})$ compared to year $2(78 \pm 1.5 \mathrm{~g} / \mathrm{kg} \mathrm{DM})$.

There was no MD effect on ADF. Acid detergent fibre was significantly $(P<0.05)$ affected by $C D$. Acid detergent fibre was lower on CD2 (214 $\pm 5.0 \mathrm{~g} / \mathrm{kg} \mathrm{DM})$ compared to CD5 (242 $\pm 9.2 \mathrm{~g} / \mathrm{kg} \mathrm{DM})$, and CD1, CD3 and CD4 (230 $\pm 5.9 \mathrm{~g} / \mathrm{kg} \mathrm{DM})$ being intermediate. Year also had an effect $(P<0.001)$ on ADF, which was lower in year $2(216 \pm 0.5 \mathrm{~g} / \mathrm{kg} \mathrm{DM})$ than year $3(242 \pm 3.8 \mathrm{~g} / \mathrm{kg} \mathrm{DM})$.

Neutral detergent fibre was significantly $(P<0.05)$ affected by $\mathrm{CD}$; CD3 (376 $\pm 8.5 \mathrm{~g} / \mathrm{kg} \mathrm{DM})$ was lower than CD1, CD2 and CD5 (401 $\pm 8.5 \mathrm{~g} / \mathrm{kg} \mathrm{DM})$ and CD4 (382 $\pm 8.5 \mathrm{~g} / \mathrm{kg} \mathrm{DM})$ was intermediate. Year significantly $(P<0.01)$ affected NDF; NDF was greater in year $3(402 \pm 4.8 \mathrm{~g} / \mathrm{kg} \mathrm{DM})$ than year 1 and year $2(380 \pm 4.8 \mathrm{~g} / \mathrm{kg} \mathrm{DM})$.

\section{Measurement Period 5}

Organic matter digestibility and $C P$ were not affected by $C D$ or year; there was no effect of $C D$ on ash content. Ash content was significantly $(P<0.001)$ lower in year $2(86 \pm 1.7 \mathrm{~g} / \mathrm{kg}$ DM) compared to year $3(93 \pm 1.74 \mathrm{~g} / \mathrm{kg} D M)$. Acid detergent fibre and NDF contents were not affected by $C D$ but were significantly $(P<0.001)$ affected by year. Both ADF and NDF were greater in year 2 (ADF - $257 \pm 5.6 \mathrm{~g} / \mathrm{kg} \mathrm{DM}, \mathrm{NDF}-443$ $\pm 8.3 \mathrm{~g} / \mathrm{kg} \mathrm{DM}$ ) compared to year 3 (ADF $-214 \pm 6.9 \mathrm{~g} / \mathrm{kg} \mathrm{DM}$, NDF $-398 \pm 10.2 \mathrm{~g} / \mathrm{kg} \mathrm{DM}$ ).

\section{Tiller density}

There was a significant effect $(P<0.01)$ of CD on PRG tiller density. Closing date 1 had a lower tiller density compared to 
CD3 and CD4, and CD2 and CD5 was intermediate to both (Figure 2). Tiller density was significantly $(P<0.001)$ greater in year $3\left(4,039 \pm 126.1\right.$ tiller $\left./ \mathrm{m}^{2}\right)$ than years 1 and 2 (average, $2,420 \pm 153.6$ tiller $\left./ \mathrm{m}^{2}\right)$. Tiller density was greater $(P<0.001)$ in spring (+629 plants per $\left.\mathrm{m}^{2}\right)$ than in autumn. There was no effect of CD on weed grass tiller density. Weed grass tiller density was significantly $(P<0.001)$ lower in year $1\left(1,174 \pm 190.3 \mathrm{tiller} / \mathrm{m}^{2}\right)$ compared to year 2 and year 3 (average 2,173 \pm 175.1 tiller $/ \mathrm{m}^{2}$ ).

\section{Leaf, stem and dead proportion}

The proportion of green leaf, stem and dead in the sward was significantly $(P<0.001)$ affected by $\mathrm{CD}$ (Table 6$)$; the green leaf proportion was lowest on CD1 and CD2. Stem and dead proportion were greatest on CD1. Stem proportion in the sward was significantly $(P<0.001)$ higher in year $1(0.15 \pm$ $0.011)$ compared to year $2(0.11 \pm 0.009)$, and year $3(0.14 \pm$ 0.010 ) was intermediate to both.



Figure 2. The effect of five autumn closing dates (CD; CD1 [27 Sept-11 Oct], CD2 [12 Oct-26 Oct], CD3 [27 Oct-10 Nov], CD4 [11 Nov-25 Nov] and CD5 [26 Nov-9 Dec]) on perennial ryegrass tiller density (tillers per $\mathrm{m}^{2}$ ) in February over 3 yr (year 1 [2016/2017], year 2 [2017/2018] and year 3 [2018/2019]) of measurement. Error bars show the standard error of the mean.

\section{Leaf, stem and dead mass}

Closing date had a significant $(P<0.001)$ effect on the green leaf mass available $(>3.5 \mathrm{~cm})$; CD1 had greater green leaf mass $(1,329 \pm 72.5 \mathrm{~kg} \mathrm{DM} / \mathrm{ha})$ compared to CD2 (933 \pm 72.7 $\mathrm{kg} \mathrm{DM} / \mathrm{ha}$ ), and both were greater than CD3, CD4 and CD5 (727 $\pm 85.9 \mathrm{~kg} \mathrm{DM} / \mathrm{ha}$; Figure 3 ). Year 2 had a significantly $(P<0.001)$ lower green leaf mass $(624 \pm 53.9 \mathrm{~kg} \mathrm{DM} / \mathrm{ha})$ compared to year 1 and year 3 (939 \pm 65.1 and 1,102 \pm 59.9 $\mathrm{kg} \mathrm{DM} / \mathrm{ha}$, respectively).

There was significantly $(P<0.001)$ greater stem mass on CD1 and CD2 (324 \pm 23.2 and $288 \pm 25.9 \mathrm{~kg} \mathrm{DM} / \mathrm{ha}$, respectively) compared to CD3, CD4 and CD5 $(105 \pm 29.9 \mathrm{~kg} \mathrm{DM} / \mathrm{ha})$. Stem mass was significantly $(P<0.001)$ greater in year 1 and year $3(228 \pm 23.6 \mathrm{~kg} \mathrm{DM} / \mathrm{ha})$ compared to year $2(102 \pm 19.0$ $\mathrm{kg} \mathrm{DM} / \mathrm{ha})$.

Closing date had a significant effect on dead mass which was higher on CD1 (319 $\pm 25.9 \mathrm{~kg} \mathrm{DM} / \mathrm{ha})$ than CD2, CD3, CD4

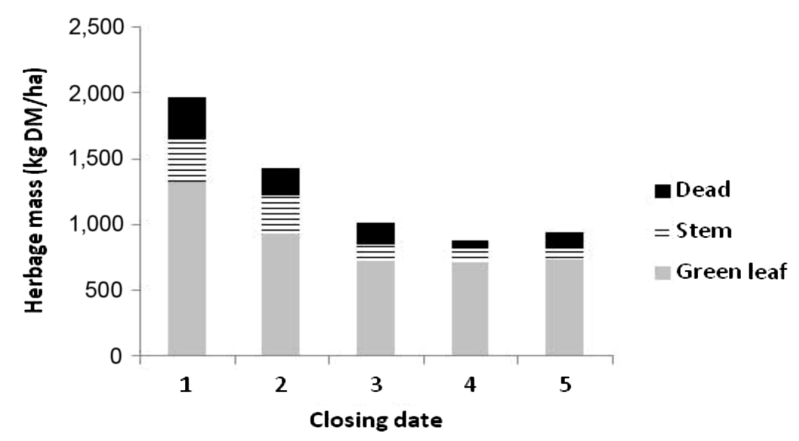

Figure 3. Herbage mass (kg DM/ha), separated into green leaf, stem and dead mass for each autumn closing date (CD; CD1 [27 Sept-11 Oct], CD2 [12 Oct-26 Oct], CD3 [27 Oct-10 Nov], CD4 [11 Nov-25 Nov] and CD5 [26 Nov-9 Dec]) on measurement date 4 [first defoliation in spring] over 3 yr (year 1 [2016/2017], year 2 [2017/2018] and year 3 [2018/2019]).

Table 6: The effect of five autumn closing dates (CD; CD1 [27 Sept-11 Oct], CD2 [12 Oct-26 Oct], CD3 [27 Oct-10 Nov], CD4 [11 Nov-25 Nov] and CD5 [26 Nov-9 Dec]) on the proportion of perennial ryegrass green leaf, stem and dead material on measurement date 4 (first defoliation in spring) over 3 yr (year 1 [2016/2017], year 2 [2017/2018] and year 3 [2018/2019])

\begin{tabular}{|c|c|c|c|c|c|c|c|}
\hline Variable & CD1 $^{1}$ & CD2 & CD3 & CD4 & CD5 & S.E. & $P$-value \\
\hline Leaf proportion ${ }^{2}$ & $0.68^{a}$ & $0.69^{a}$ & $0.74^{\mathrm{ab}}$ & $0.80^{\mathrm{b}}$ & $0.80^{\mathrm{b}}$ & 0.020 & $* * *$ \\
\hline Stem proportion ${ }^{3}$ & $0.16^{\mathrm{ab}}$ & $0.17^{\mathrm{a}}$ & $0.12^{\mathrm{ab}}$ & $0.11^{\mathrm{ab}}$ & $0.10^{\mathrm{b}}$ & 0.071 & * \\
\hline Dead proportion ${ }^{4}$ & $0.16^{\mathrm{a}}$ & $0.14^{\mathrm{ab}}$ & $0.14^{\mathrm{ab}}$ & $0.09^{\mathrm{c}}$ & $0.10^{\mathrm{bc}}$ & 0.015 & * \\
\hline
\end{tabular}

a,b,cWithin a row, means values with different superscripts differ significantly.

${ }^{1}$ Autumn closing date applied to swards: CD1 $=27$ Sept-11 Oct, CD2 = 12 Oct-26 Oct, CD3 = 27 Oct-10 Nov, CD4 = 11 Nov-25 Nov and CD5 = 26 Nov-9 Dec.

${ }^{2}$ Proportion of leaf above $3.5 \mathrm{~cm}$.

${ }^{3}$ Proportion of stem material above $3.5 \mathrm{~cm}$.

${ }^{4}$ Proportion of dead material above $3.5 \mathrm{~cm}$. 
and CD5 (140 $\pm 29.2 \mathrm{~kg} \mathrm{DM} / \mathrm{ha})$. Dead mass $(>3.5 \mathrm{~cm})$ was significantly $(P<0.001)$ lower in years 1 and $2(153 \pm 22.9$ and $112 \pm 21.1 \mathrm{~kg} \mathrm{DM} / \mathrm{ha}$, respectively) than in year 3 (264 \pm $21.1 \mathrm{~kg} \mathrm{DM} / \mathrm{ha})$.

\section{Discussion}

For each extra day swards were closed from the end of September to the start of December (CD1 to CD5), an additional $16 \mathrm{~kg} \mathrm{DM} / \mathrm{ha}$ was available in spring. This is similar to O'Donovan et al. (2002) who reported $15 \mathrm{~kg} \mathrm{DM} / \mathrm{ha}$, but greater than Lawrence et al. (2017) and Ryan et al. (2010) who reported $10 \mathrm{~kg} \mathrm{DM} / \mathrm{ha}$ and $12.4 \mathrm{~kg} \mathrm{DM} / \mathrm{ha}$, respectively. However, lengthening the period of time a sward is closed for can result in an increase in dead and stem material (Lawrence et al., 2017). In the current experiment each additional day closed from late September to early December increased dead mass by $2.5 \mathrm{~kg} \mathrm{DM} / \mathrm{ha}$ per day and stem mass by $2.5 \mathrm{~kg} \mathrm{DM} /$ ha per day. As a result, only $11 \mathrm{~kg} \mathrm{DM} / \mathrm{ha}$ of the $16 \mathrm{~kg} D M /$ ha was green leaf mass. Swards closed in late September and in October (CD1 and CD2) had greater growth rates over winter (MD1 and MD2) than swards closed in late October and November (CD3 and CD4), similar to Ryan et al. (2010). In the subsequent spring grazing (second rotation; MD5), swards closed in late November and early December (CD5) had greater growth rates compared to swards closed in late September and October (CD1 and CD2) in the current study. A possible explanation for this is the reduction in tiller density on the earlier closed swards, which decreases the number of growing points (Garay, 1999 ) in the sward at the initiation of grass growth in spring which might lead to this reduction in growth rate. Although not measured in the current study, in high herbage masses it is also a possibility that there is old leaf or dead material left below the grazing horizon ( $<4 \mathrm{~cm}$ ) (Lawrence et al., 2017). This old leaf material is less photosynthetically efficient than new leaf material (Parmenter \& Boswell, 1983). Another reason for reduced growth rates in spring for swards closed in late September and October could be lower water-soluble carbohydrate content in the residual (Looney et al., 2019). Water-soluble carbohydrates are required for the supply of energy for growth and function post defoliation (White, 1973). The regrowth is mostly driven by water-soluble carbohydrate reserves at $4 \mathrm{~cm}$ above ground level (Donaghy \& Fulkerson, 1998), and as such is a fundamental element in the regrowth of swards post defoliation. The increased growth rate in later-closed swards once defoliated in spring, in the current study, is contradictory to Lawrence et al. (2017) who reported no effect of CD on subsequent growth rates following initial spring defoliation. This may be a result of the defoliation method; Lawrence et al. (2017) mechanically harvested swards which may not accurately reflect the impact of animal grazing on herbage growth (Cashman et al., 2016). Targeting high herbage masses, from swards closed in late September and October, for early defoliation may encourage more green herbage and a lower proportion of dead material in subsequent defoliations (Korte et al., 1984) and counteract reduced growth rates in the subsequent defoliation. Early defoliation will also allow for a lengthier regrowth interval prior to the subsequent defoliation and allow utilisation of applied nitrogen (O'Donovan et al., 2004).

In the current study there was a large year-to-year variation in over-winter growth rates and spring grass availability similar to that reported by Brereton et al. (1985), Carton et al. (1989) and Hennessy et al. (2006). Most likely, the year-toyear variation was a result of climatic conditions. Climatic conditions, particularly soil and air temperature, have the greatest influence on over-winter growth rates (Peacock, 1975). The range in growth rates led to a significant variation in pre-grazing herbage mass on the first spring defoliation (MD4) in the 3-yr study, similar to Hennessy et al. (2006). In year 2, there was a lower average pre-grazing herbage mass compared to year 1 and year 3 which can be attributed to the lower average soil and air temperature $\left(-0.8^{\circ} \mathrm{C}\right)$. Although there was large year-to-year variation in the study, $50 \%\left(R^{2}=\right.$ 0.5023 ) of the variation in spring grass availability was associated with the number of days the sward was closed from grazing. The other $50 \%$ of pre-grazing herbage mass in spring was a result of uncontrollable factors such as meteorological conditions, that is, soil and air temperature, solar radiation and moisture. Controllable factors such as fertiliser application, PRG content in autumn and management were accounted for within the experimental design.

In the current study, a higher pre-grazing herbage mass in spring resulted in a reduction in PRG tiller density. Therefore, similar to Laidlaw et al. (2000), Hennessy et al. (2006) and Lawrence et al. (2017), the current study confirms the negative impact of early $C D$ on tiller density. Restricted access to light due to higher herbage masses can cause tiller bud suppression (Hunt, 1978) which can result in the loss of daughter tillers (Korte, 1981). Low light interception at the base of the plant in high pre-grazing herbage mass swards inhibits the production of new tillers (Baker, 1956). Survival of mature tillers at the expense of smaller/younger ones (self-thinning) can occur due to these low light conditions (Laidlaw \& Mayne, 2000). When there is a requirement for increased pre-grazing herbage mass in spring, swards closed in late September and October should be defoliated as early as possible in spring to allow light interception at the base of the plant (Brougham, 1960) to promote new tiller production (Kays \& Harper, 1974; Laidlaw \& Mayne, 2000). This might compensate for the reduction in tiller production over winter in earlier-closed swards. Earlier defoliation of swards in spring 
with high herbage masses can also result in an improvement in sward quality in subsequent rotations (Garry et al., 2015).

Sward quality in spring is impacted by autumn closing management (Hennessy et al., 2006; Lawrence et al., 2017). A higher pre-grazing herbage mass in spring results in reduced herbage quality as a result of increased dead material (Binnie et al., 2001) in swards closed in late September and October. However, even if OMD, CP and ADF are lower in swards closed in late September and October (CD1 and CD2), nutritional requirements for a dairy cow in early to peak lactation are still met (Kavanagh, 2016) from grazed grass. The quality of PRG in grazed paddocks (average OMD = $826 \mathrm{~g} / \mathrm{kg} \mathrm{DM}$ ) closed in late September and early October (CD1 and CD2) reported in this study is still greater than the medium quality silage (DM digestibility [DMD] = $696 \mathrm{~g} / \mathrm{kg} \mathrm{DM}$ ) reported by Kennedy et al. (2005). Increasing the proportion of grazed grass in the diet in the place of silage, regardless of autumn CD, will increase animal production (Kennedy et al., 2005; Claffey et al., 2019). In this study, after the initial spring grazing, no carryover effect of autumn CD was observed on sward quality in the subsequent spring defoliation (MD5), a result similar to Lawrence et al. (2017).

The current study reported that the proportion of green leaf was greater in swards closed in November and early December (CD4 and CD5; +0.12) compared to swards closed in late September and October (CD1 and CD2) similar to Lawrence et al. (2017) and Hennessy et al. (2006). Likewise, the proportion of dead material in the sward was greatest in swards closed in late September and October, similar to Davies and Simons (1979), Hennessy et al. (2006) and Ryan et al. (2010). Green leaf is of higher nutritional value than stem and dead material (Binnie et al., 2001; Beecher et al., 2015). Lawrence et al. (2017) reported a correlation of $\mathrm{R}^{2}=0.78$ between green leaf proportion and DMD in autumn. In spring, the current study found a correlation of $R^{2}=0.61$ between green leaf proportion and OMD. The lower correlation reported in the current study could possibly be due to the higher quality of grass in spring compared to autumn (McDonald, 2002). Swards with a greater green leaf proportion have greater nutritional value but the proportion of green leaf does not reflect the quantity of herbage available. In the current study, although swards closed in November and early December had a greater green leaf proportion, swards closed in September and early October had a greater quantity of green leaf mass available in spring. Reporting the proportion and mass of green leaf, stem and dead should give a more accurate representation of the sward morphology available for grazing. Previous research (Beecher et al., 2015) reported that the available OMD is greatest in the leaf compared to stem and dead material. They reported that OMD in February was greatest in the green leaf component $(751 \mathrm{~g} / \mathrm{kg})$ compared to stem and dead material (658 and $541 \mathrm{~g} / \mathrm{kg}$, respectively).
In terms of dry organic matter $(\mathrm{kg}$ DOM; OMD g/kg DM $\times \mathrm{kg}$ $\mathrm{DM} / \mathrm{ha}$ ), in the current study there was $52 \%$ more available digestible material in earlier-closed swards (CD1; 1,273 kg $\mathrm{DOM} / \mathrm{ha}$ ) compared to later-closed swards (CD4; $664 \mathrm{~kg}$ $\mathrm{DOM} / \mathrm{ha}$ ). Although earlier closing of swards can result in an increase in stem and dead material and a reduction in overall sward quality, the available material to grazing animals $(<3.5$ $\mathrm{cm}$ ) can have a greater green leaf mass, which, combined with an increase in consumed herbage quality, can increase animal performance. Available green leaf mass combined with DOM should be considered as a means to improving grazing management decisions on farm.

The results of this research have highlighted the success early autumn closing management has on increasing the herbage mass available to meet increased demand for spring grass in an intensive dairy production system. To meet increased feed demand in spring, farmers must adopt an earlier closing of paddocks in autumn. If implemented, this will be beneficial in terms of industry targets to increase production and utilisation of grazed grass, particularly in spring where a deficit has been identified. Successfully managing earlier-closed swards on farm should prioritise early defoliation in spring to help maintain quality and allow a longer regrowth interval to compensate for the lower spring regrowth potential of early closed swards. The year-to-year variation in over-winter growth rates must be considered in grassland management decisions on farm to ensure spring herbage targets are met. A move away from grazing targets based on date, as is currently recommended (Teagasc, 2011), to target pasture cover in autumn will result in a more consistent supply of grass in the following spring. Future research should investigate the impact of different spring defoliation dates on various herbage masses to determine grazing dates that maximise utilisation of swards and reduce carryover effects of autumn closing management into the second rotation.

\section{Acknowledgements}

The authors wish to thank A. Claffey for her work on the trial and J.P. Murphy, M. Liddane, A. McGrath and P. O'Connor for their technical assistance and all the staff of Moorepark research farm for their assistance with measurements during the experiment. This experiment was funded by Irish Dairy Levy Funding administered by Dairy Research Ireland and the Teagasc Walsh Scholarship programme.

\section{References}

Alexander, S., Black, A., Boland, A., Burke, J., Carton, O.T., Coulter, B.S., Humphreys, J. 2008. "Major and Micro Nutrient Advice 
for Productive Agricultural Crops", 50th anniversary Edition ed: Teagasc, Johnstown Castle, Co Wexford.

AOAC International. 1990. "Official Methods of Analysis", 15th Edition, AOAC International, Arlington, VA.

AOAC International. 1995. "Official Methods of Analysis", 16th Edition (ed. P. Cunniff), AOAC International, Arlington, VA.

Baker, H. 1956. Note on the influence of previous management on the death of perennial ryegrass during winter. Grass and Forage Science 11: 235-237.

Beecher, M., Hennessy, D., Boland, T., McEvoy, M., O’Donovan, M. and Lewis, E. 2015. The variation in morphology of perennial ryegrass cultivars throughout the grazing season and effects on organic matter digestibility. Grass and Forage Science 70: 19-29.

Binnie, R., Mayne, C. and Laidlaw, A. 2001. The effects of rate and timing of application of fertilizer nitrogen in late summer on herbage mass and chemical composition of perennial ryegrass swards over the winter period in Northern Ireland. Grass and Forage Science 56: 46-56.

Brereton, A., Carton, O. and O'Keeffe, W. 1985. Tissue turnover in perennial ryegrass (Lolium perenne L.) during winter. Irish Journal of Agricultural Research 24: 49-62.

Brougham, R. 1960. The effects of frequent hard grazings at different times of the year on the productivity and species yields of a grassclover pasture. New Zealand Journal of Agricultural Research 3: 125-136.

Carton, O.T., Brereton, A.J., O'Keeffe, W.F. and Keane, G.P. 1988. Effects of autumn closing date and grazing severity in a rotationally grazed sward during winter and spring: 1. Dry matter production. Irish Journal of Agricultural Research 27: 141-150.

Carton, O., Brereton, A., O'Keeffe, W. and Keane, G. 1989. Effect of turnout date and grazing severity in a rotationally grazed reproductive sward: 1. Dry matter production. Irish Journal of Agricultural Research 28: 153-163.

Cashman, P., McEvoy, M., Gilliland, T. and O'Donovan, M. 2016. A comparison between cutting and animal grazing for dry matter yield, quality and tiller density of perennial ryegrass cultivars. Grass and Forage Science 71: 112-122.

Claffey, A., Delaby, L., Galvin, N., Boland, T. and Egan, M. 2019. The effect of spring grass availability and grazing rotation length on the production and quality of herbage and milk in early spring. The Journal of Agricultural Science 157: 434-448.

Claffey, A., Delaby, L., Boland, T. and Egan, M. 2020. Implications of adapting autumn grazing management on spring herbage production - the effect on late lactation milk production and the subsequent response in early lactation animal performance. Livestock Science 231: 103870.

Davies, A. and Simons, R. 1979. Effect of autumn cutting regime on developmental morphology and spring growth of perennial ryegrass. The Journal of Agricultural Science 92: 457469.

Delaby, L., Peyraud, J.-L., Bouttier, A. and Peccatte, J.-R. 1998. Effet d'une réduction simultanée de la fertilisation azotée et du chargement sur les performances des vaches laitières et la valorisation du pâturage. Annales de Zootechnie 47: 17-39.

Dillon, P., Crosse, S., Stakelum, G. and Flynn, F. 1995. The effect of calving date and stocking rate on the performance of springcalving dairy cows. Grass and Forage Science 50: 286-299.

Dillon, P., Shalloo, L., Wallace, M. and Butler, A. 2005. Integrated modelling of dairy production systems under technical, environmental and economic scenarios. Journal of Theoretical Biology 112: 345-367.

Dillon, P., Hennessy, T., Shalloo, L., Thorne, F. and Horan, B. 2008. Future outlook for the Irish dairy industry: a study of international competitiveness, influence of international trade reform and requirement for change. International Journal of Dairy Technology 61: 16-29.

Dillon, P., Ring, S., Shalloo, L., O’Brien, D., Butler, S., Berry, D. and Cromie, A. 2018. EBI-20 Years On Past Present and Future. Paper presented at the Genetics Conference, Cork, Ireland, 6th December 2018. Retrieved from https://www.icbf.com.

Donaghy, D.J. and Fulkerson, W.J. 1998. Priority for allocation of water-soluble carbohydrate reserves during regrowth of Lolium perenne. Grass and Forage Science 53: 211-218.

Donnellan, T., Hanrahan, K. and Lanigan, G. 2018. Future Scenarios for Irish Agriculture: Implications for Greenhouse Gas and Ammonia Emissions. Teagasc, Athenry. June 2018.

Finneran, E., Crosson, P., O'kiely, P., Shalloo, L., Forristal, D. and Wallace, M. 2010. Simulation modelling of the cost of producing and utilising feeds for ruminants on Irish farms. Journal of Farm Management 14: 95-116.

Ganche, E., Delaby, L., O'Donovan, M., Boland, T., Galvin, N. and Kennedy, E. 2013. Post-grazing sward height imposed during the first 10 wk of lactation: Influence on early and total lactation dairy cow production, and spring and annual sward characteristics. Livestock Science 157: 299-311.

Garay, A.H. 1999. Tiller size/density compensation in perennial ryegrass miniature swards subject to differing defoliation heights and a proposed productivity index. Grass and Forage Science 54: 347-356.

Garry, B., Kennedy, E., Baumont, R., Boland, T., Wright, M., O'Donovan, M. and Lewis, E. 2015. Comparing the in vivo dry matter digestibility of perennial ryegrass in sheep and dairy cows. In Proceedings of the 18th Symposium of the European Grassland Federation, Wageningen, the Netherlands, 15-17 June 2015 'Grassland and Forages in High Output Dairy Farming Systems'. Grassland Science in Europe 20: 416-418.

Hanrahan, L., McHugh, N., Hennessy, T., Moran, B., Kearney, R., Wallace, M. and Shalloo, L. 2018. Factors associated with profitability in pasture-based systems of milk production. Journal of Dairy Science 101: 5474-5485.

Hennessy, D., O'Donovan, M., French, P. and Laidlaw, A. 2006. Effects of date of autumn closing and timing of winter grazing on herbage production in winter and spring. Grass and Forage Science 61: 363-374. 
Hennessy, D., O'Donovan, M., French, P. and Laidlaw, A. 2008. Factors influencing tissue turnover during winter in perennial ryegrass dominated swards. Grass and Forage Science 63: 202-211.

Hunt, R. 1978. Demography versus plant growth analysis. New Phytologist 80: 269-272.

ICBF. 2018. Dairy cow numbers. Available online: https://www.icbf. com/wp/?page_id=313.

Jewiss, O. 1993. Shoot development and number. Sward Measurement Handbook. Reading, UK. The British Grassland Society 99-120.

Kavanagh, S. 2016. Feeding the dairy cow. In: (ed. Teagasc), Teagasc Dairy Manual.

Kays, S. and Harper, J.L. 1974. The regulation of plant and tiller density in a grass sward. The Journal of Ecology 62: 97-105.

Kelly, P., Shalloo, L., Wallace, M. and Dillon, P. 2020. The Irish dairy industry - Recent history and strategy, current state and future challenges. Dairy Technology 73: 309-323.

Kennedy, E., O'Donovan, M., Murphy, J.P., Delaby, L. and O'Mara, F. 2005. Effects of grass pasture and concentrate-based feeding systems for spring-calving dairy cows in early spring on performance during lactation. Grass and Forage Science 60: 310-318.

Korte, C.J. 1981. Studies of late spring grazing management in perennial ryegrass dominant pasture: a thesis presented in partial fulfilment of the requirements for the degree of $\mathrm{PhD}$ in Agronomy at Massey University. (Doctor of Philosophy (Ph.D.) Doctoral), Massey University. Available online: http://hdl.handle.net/10179/3334.

Korte, C., Watkin, B. and Harris, W. 1984. Effects of the timing and intensity of spring grazings on reproductive development, tillering, and herbage production of perennial ryegrass dominant pasture. New Zealand Journal of Agricultural Research 27: 135-149.

Laidlaw, A. and Mayne, C. 2000. Setting management limits for the production and utilization of herbage for out-of-season grazing. Grass and Forage Science 55: 14-25.

Laidlaw, A., Watson, C. and Mayne, C. 2000. Implications of nitrogen fertilizer applications and extended grazing for the $\mathrm{N}$ economy of grassland. Grass and Forage Science 55: 37-46.

Lawrence, D.C., O'Donovan, M., Boland, T.M. and Kennedy, E. 2017. Effects of autumn and spring defoliation management on the drymatter yield and herbage quality of perennial ryegrass swards throughout the year. Grass and Forage Science 72: 38-49.

Looney, C., Wingler, A., Donaghy, D. and Egan, M. 2019. The effect of altering autumn closing management on the watersoluble carbohydrate composition of perennial ryegrass (Lolium perenne L.) the following spring. In Proceedings of the Joint 20th Symposium of the European Grassland Federation and the 33rd Meeting of the EUCARPIA 'Improving sown grasslands through breeding and management' Zürich, Switzerland, 24-27 June 2019. Grassland Science in Europe 24: 167-169.

MacDonald, K., Glassey, C. and Rawnsley, R. 2010. The emergence, development and effectiveness of decision rules for pasture based dairy systems. In Proceedings of the 4th Australasian Dairy Science Symposium 2010. pp 199-209.
McCarthy, B., Pierce, K., Delaby, L., Brennan, A., Fleming, C. and Horan, B. 2013. The effect of stocking rate and calving date on grass production, utilization and nutritive value of the sward during the grazing season. Grass and Forage Science 68: 364-377.

McDonald, P. 2002. Animal nutrition. (eds. P. McDonald, R.A. Edwards, J.F.D. Greenhalagh and C.A. Morgan), Pearson Education Limited, United Kingdom.

Morgan, D., Stakelum, G. and Dwyer, J. 1989. Modified neutral detergent cellulase digestibility procedure for use with the 'Fibertec' system. Irish Journal of Agricultural Research 28: 91-92.

O'Donovan, M., Dillon, P., Reid, P., Rath, M. and Stakelum, G. 2002. A note on the effects of herbage mass at closing and autumn closing date on spring grass supply on commercial dairy farms. Irish Journal of Agricultural and Food Research 41: 265-269.

O'Donovan, M., Delaby, L., Stakelum, G. and Dillon, P. 2004. Effect of autumn/spring nitrogen application date and level on dry matter production and nitrogen efficiency in perennial ryegrass swards. Irish Journal of Agricultural and Food Research 43: 31-41.

O'Donovan, M., Lewis, E. and O'Kiely, P. 2011. Requirements of future grass-based ruminant production systems in Ireland. Irish Journal of Agricultural and Food Research 50: 1-21.

Parmenter, G. and Boswell, C. 1983. Effect of number and timing of winter grazings on winter and spring pasture production. New Zealand Journal of Experimental Agriculture 11: 281-287.

Parsons, A. and Chapman, D. 2000. The principles of pasture growth and utilization. In "Grass: its Production and Utilization", (ed. A. Hopkins), Blackwell Science Ltd, Oxford, UK, pages 31-89.

Peacock, J.M. 1975. Temperature and leaf growth in Lolium perenne III factors affecting seasonal differences. Journal of Applied Ecology 12: 685-697.

Peyraud, J., van den Pol, A., Dillon, P. and Delaby, L. 2010. Producing milk from grazing to reconcile economic and environmental performances. Paper presented at the 23th General Meeting of the European Grassland Federation, Kiel, Germany, 29 August-02 September, 2010.

Ramsbottom, G., Horan, B., Berry, D.P. and Roche, J.R. 2015. Factors associated with the financial performance of spring-calving, pasturebased dairy farms. Journal of Dairy Science 98: 3526-3540.

Roche, J.R., Dillon, P., Crosse, S. and Rath, M. 1996. The effect of closing date of pasture in autumn and turnout date in spring on sward characteristics, dry matter yield and milk production of spring-calving dairy cows. Irish Journal of Agricultural and Food Research 35: 127-140.

Ryan, W., Hennessy, D., Murphy, J. and Boland, T. 2010. The effects of autumn closing date on sward leaf area index and herbage mass during the winter period. Grass and Forage Science 65: 200-211.

Teagasc. 2011. Grazing Guide. Available online: https://www. teagasc.ie/media/website/crops/grassland/Grazing-GuideBook-2011_22-26.pdf https://www.teagasc.ie/media/website/ crops/grassland/Grazing-Guide-Book-2011_49-69.pdf.

Teagasc. 2017. Moorepark Farm Profile. Available online: https:// www.teagasc.ie/animals/dairy/research-farms/moorepark/. 
Teagasc. 2019. Autumn Grazing management. Available online: https://www.teagasc.ie/crops/grassland/grass10/grazingmanagement/autumn-grazing-management/.

Teagasc. 2020. Spring Grazing Management. Available online: https:// www.teagasc.ie/crops/grassland/grass10/grazing-management/ spring-grazing-management/.
Van Soest, P.J., Robertson, J.B. and Lewis, B.A. 1991. Methods for dietary fiber, neutral detergent fiber, and nonstarch polysaccharides in relation to animal nutrition. Journal of Dairy Science 74: 3583-3597.

White, L.M. 1973. Carbohydrate reserves of grasses: a review. Rangeland Ecology \& Management/Journal of Range Management Archives 26: 13-18. 